\title{
DERECHO EIECTORAL
}

\section{Redes sociales y eventos comiciales: reflexiones a las puertas de una nueva elección}

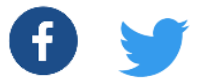

Nota del Consejo Editorial

Recepción: 22 de abril de 2019.

Revisión, corrección y aprobación: 29 de mayo de 2019.

Resumen: Las redes sociales son una realidad en los procesos electorales y, consecuentemente, en las campañas. Por ello y ante la proximidad de un nuevo evento comicial, resulta oportuno referirse a esa nueva forma de conectarse con los votantes, para lo cual el artículo aborda el fenómeno desde tres dimensiones concretas: a) eventuales hipótesis (no exhaustivas) de qué pasa en las redes y el porqué de la fascinación en su uso; b) el camino andado desde el organismo electoral costarricense tratándose de su regulación; y c) cuáles son las respuestas que pueden darse ante estos fenómenos: la legislativa y la de control de actores no necesariamente institucionales.

Palabras clave: Estrategias electorales / Redes sociales / Comunicación electrónica / Proceso electoral / Campaña política / Derecho informático / Delitos electorales / Delito informático.

Abstract: Social networks are a reality in electoral processes; consequently, in political campaigns. In light of this, and considering the proximity of a new electoral event, the new ways of connecting with voters turn out to be a suitable topic to be analyzed and approached from three specific dimensions: a) eventual (not exhaustive) hypothesis about what happens in these networks and the cause of their usage fascination; b) the path travelled by Costa Rican Electoral Body concerning these networks' regulations; and, c) which may be the answers to these phenomena: legislation and the control of non-institutionalized actors.

Key Words: Electoral strategies / Social networks / Electronic communication / Electoral processes / Political campaign / Computer law / Electoral offenses / Computer crime.

\footnotetext{
* Costarricense, abogado y criminólogo. Correo electrónico: acambronero@tse.go.cr. Letrado de la Presidencia del TSE y profesor de la línea curricular de Teorías y Filosofía del Derecho en la Facultad de Derecho de la UCR. Doctor en Derecho, magíster en Justicia Constitucional y licenciado en Derecho por la Universidad de Costa Rica (UCR). Diploma de especialización en Justicia Constitucional y Tutela Jurisdiccional de los Derechos por la Universidad de Pisa, Italia. Bachiller en Ciencias Criminológicas por la Universidad Estatal a Distancia (UNED). Director del Área de Gestión de la Calidad de la Facultad de Derecho de la UCR, miembro del Consejo asesor e integrante de la Comisión de Docencia, ambos, de esa unidad académica.
} 


\section{DERECHO ELECTORAL}

\section{Cuestiones introductorias}

Uno de los aspectos más apasionantes del fenómeno electoral es que siempre trae consigo algo nuevo; la palpable conexión entre los comicios (como acto institucionalizado para renovar los cuadros de gobierno) y la dimensión sociohistórica en la que los sujetos partícipes de ese proceso se encuentran insertos son los factores que nutren esa constante mutabilidad.

En parte, la formulación clásica alemana que califica a la reforma electoral como aquella que nunca termina es una manifestación concreta de cómo siempre la tuerca habrá de necesitar un ajuste; el metal una pulida y la calibración un afinamiento en aras de mejorar el rito que disipa nuestro instinto de irnos a los golpes por el poder, como lo sostiene Simmel (1939).

Por otra parte, en los tiempos que corren, los cambios vertiginosos propiciados por la tecnología han impactado las dinámicas electivas, al tiempo que han obligado a las autoridades electorales a replantearse categorías tradicionales, a revisar los contenidos de ciertas normas para evaluar su aplicabilidad a lo 2.0 y a iniciar una reflexión en punto a cuál debe ser el tratamiento de novísimos fenómenos como las noticias falsas, los trolls, los bots y un largo etcétera en constante expansión.

La tecnología ha permitido "acercar" a los individuos dispersos por el orbe; actualmente, se puede tener una charla -en tiempo real- con una persona en casi cualquier parte del planeta, basta tener una conexión a Internet. Hoy Facebook, WhatsApp, FaceTime, Skype, Telegram, Instagram y hasta Snapchat nos permiten escuchar (interactuar con) a nuestros interlocutores, así se hallen a miles de kilómetros. Hemos, en algún modo, suturado el abismo espacio-tiempo que nos separa de otros. El uso de estas posibilidades tecnológicas tiene la bondad, además, de darnos el chance de introducir filtros, editar respuestas, sustituir palabras por emojis, escondernos, fingir la pérdida de conexión para pensar un poco más reposadamente el punto. Incluso, si estamos en una supuesta dinámica vis a vis siempre habrá un lente que separa los iris, una postura cómplice que disfraza algún tremor espontáneo, una falsa sensación de seguridad.

Cual si se tratara de una versión digital de uno de los postulados de la conocidísima psicología de las masas freudiana, muchas personas se atreven a reaccionar y a expresarse en la red de formas que en vivo serían impensables para ellos. El soporte de la colectividad web parece ser una patente de corso en sí misma para obviar límites, es el analgésico para los 


\section{DERECHO EIECTORAL}

frenos inhibitorios y el incentivo que empuja a los cibernautas a no diferir la gratificación de dar, a placer, desde una opinión hasta una ofensa.

Tratándose de las dinámicas electorales, la irrupción de las redes sociales en las campañas ha traído consigo aportes positivos como el abaratamiento de la etapa de propaganda ${ }^{1}$, pero también ha despertado suspicacias tales como las que germinaron al calor de la fase postelectoral de los comicios presidenciales estadounidenses, según lo han informado, entre otros, medios como el New York Times: "Rusia creó perfiles falsos de estadounidenses para influenciar en las elecciones" (Shane, 2017).

Por ello y en razón de que próximamente se llevará a cabo un proceso electoral municipal (donde se esperan millares de candidaturas y cada una de ellas puede utilizar una o varias redes), resulta importante poner en discusión algunas ideas acerca de esa nueva forma de hacer política. El ejercicio se hará desde tres dimensiones concretas: a) eventuales hipótesis (no exhaustivas) de qué pasa en las redes y de por qué resulta tan cautivador su uso; b) el camino andado desde el organismo electoral costarricense tratándose de su regulación; y c) cuáles son las respuestas que pueden darse ante estos fenómenos: la legislativa y la del control en manos de actores no necesariamente institucionales.

\section{LAS REDES SOCIALES: SOCIALIZACIÓN E INTERACCIÓN. ¿QUÉ PASA EN SU USO?}

Las nuevas generaciones han sido educadas en una sociedad que tiende - cada vez más- a tecnologizarse e interactuar en el mundo virtual. Hoy, las redes sociales ocupan un lugar de gran relevancia en las dinámicas comunicativas, lo cual incide en cómo se participa de la vida social y cómo se estructuran las expectativas del conglomerado.

Estos servicios basados en la web permiten a sus usuarios construir un perfil -público o semipúblico- dentro de un espacio virtual que se contrae o se expande según la magnitud de la lista de otros usuarios con los que se ha deseado tener relación (Ayala, 2014). Las mencionadas redes sirven para proyectarse a los demás con la justificación, real o ficcionada, de tener algún rasgo personal o temas en común.

\footnotetext{
${ }^{1}$ Ideal recogido en el artículo 5 de la Carta Democrática Interamericana, firmada en 2001.
} 


\section{DERECHOELECTORAL}

Precisamente, la apertura de perfiles de candidatos se da con ocasión de la búsqueda de seguidores y para fomentar un campo en el que se sienta una verdadera cercanía y calidez con quienes buscan el favor electoral. Eso sí, la consecución con mayor o menor éxito de tal empresa dependerá de cómo sea utilizada la red: actualmente no basta el mero posteo de información, los usuarios de las redes requieren respuestas, comentarios, reacciones; en fin, interacción.

Importa señalar que ese intercambio debe tomar en cuenta la predilección por la baby food. Adorno critica fuertemente la cultura (industria) de masas en tanto vuelca al individuo hacia una rutina que, en aparente libertad, lo lleva a generar necesidades de consumo de productos administrados; todo está predigerido y la autorreflexión permanente se apoya en la compulsión infantil de repetición en el marco de los requerimientos que ese tipo de cultura crea (Adorno, 2007). En relación con los comicios, el arma de los candidatos son mensajes en redes certeros, donde la brevedad y la sencillez sean los pilares comunicativos; además, la fácil conexión con referentes intercompartidos de necesidades (más seguridad, políticas de empleo, contención del gasto público, mejora infraestructural, etc.) facilita -sin duda- la aceptación de lo que se dice.

En este terreno, el colado está representado por un discurso político que tienda puentes con expectativas simbólicas preformadas; resultará más sencillo despertar el aplauso mediante un brevísimo tuit que se comprometa a mejorar el alumbrado público, como estrategia para disminuir los asaltos en un punto específico del cantón ${ }^{2}$, que un elaborado programa de seguridad ciudadana que requiera explicar la multicausalidad del fenómeno criminal.

Ahora bien, retomando el concepto de interacción, es más que oportuno referirse al interaccionismo simbólico, principalmente en lo relativo a los planteamientos de G.H. Mead ${ }^{3}$. Una de sus ideas principales es que todo empieza con el juego infantil donde se asumen roles, pero también la génesis está en el deporte, donde se lleva a un accionar (no solo hay roles sino también reglas y respuestas esperadas). Esto se puede aplicar a los

\footnotetext{
2 Recuérdese lo que señalaba Le Bon (1995, p. 130): "Al elector le gusta que le halaguen sus ambiciones y sus vanidades; el candidato ha de abrumarle con extravagantes y serviles adulaciones y no vacilar en hacerle las más fantásticas promesas".

${ }^{3}$ Sobre el interaccionismo simbólico se recomienda Mead (1913 y 2004) y Ritzer (1993). En igual sentido, resulta de obligada consulta la obra póstuma Mind, Self and Society (1934), en la que se recoge la esencia del posicionamiento de Mead.
} 


\section{DERECHO ELECTORAL}

movimientos sociales generados desde las redes, por ejemplo, las movilizaciones que se producen por medio de la invitación a ciertos eventos, convocatorias y marchas.

Para mencionar algunos casos, se puede partir desde la propia tenencia del perfil. En efecto, estar hoy en una de estas redes se da por presupuesto: es una expectativa que tiene el colectivo sobre los individuos y estos, según tales pautas sociales, son empujados a tenerlos. Para ilustrar el punto, piénsese en cómo las instituciones públicas -cada vez con mayor frecuencia- divulgan sus mensajes por sus perfiles oficiales, dándose por sentado que, de hecho, una gran porción de los habitantes se encuentra en tales espacios virtuales. Para decirlo con palabras propias de la referida corriente sociológica angloamericana, pareciera que el otro generalizado de ciudadano se fragua en una expectativa simbólica de ser propietario de una cuenta en una red social.

De otra parte, el elemento amplificador de las redes sociales supone un punto de encuentro con el interaccionismo simbólico: un posteo es una invitación (estímulo) a la comunidad de "seguidores" o "amigos" a reaccionar. En efecto, la capacidad de despertar tales signos significantes hoy supone un nicho de mercado: los denominados influencers son personas que por su capacidad de generar en otros reacciones (normalmente de consumo de contenidos, productos o, en el plano político, la adscripción a un candidato) son reclutados para levantar cierta estrategia de mercadeo o de comunicación política. Sin duda, como ya está ocurriendo, esos influenciadores serán parte obligada de las planillas y contrataciones en los períodos de campaña, cuya valía dependerá de la credibilidad y cantidad de seguidores que hayan podido ir reclutando a través del tiempo.

En otro orden de ideas, deben hacerse modulaciones del referente teórico en comentario para su adecuada aplicación al tema en desarrollo. Un like (el famoso "me gusta") puede comportarse, en algunos escenarios, como un símbolo no significante: es la respuesta instintiva o poco reposada a, por decir algo, una publicación en la que se cuestiona una política pública o se muestra el beneplácito hacia una determinación de su tendencia (normalmente de crítica hacia uno de sus contendores o hacia el Gobierno); empero, en otros contextos, ese like puesto en una fotografía (o serie de ellas) puede generar un contenido significativo que simboliza atracción, el interés de establecer una amistad ( $\mathrm{si}$ es que se trata de desconocidos) o, de gran relevancia para la construcción de estrategias políticas futuras, el reconocimiento a una conducta del candidato (imagínese una imagen del 
postulante conversando con representantes de una población vulnerable o realizando un donativo).

Ahora bien, vale indicar, en otra temática, que muchas iniciativas suelen comenzar en las redes sociales (como la movilización por un Estado laico en Costa Rica y la marcha del $8 \mathrm{M}^{4}$ ), pero estas solo "se convierten en movimiento al ocupar el espacio urbano, ya sea mediante la ocupación permanente de plazas públicas o por las manifestaciones continuas" (Castells, 2012); esas acciones hacen alusión más a encuentros físicos del grupo para plantear sus exigencias en sitios específicos que a "presencia virtual". No obstante, podría evaluarse si hoy, en la interacción que generan los movimientos, debe incluirse el espacio cibernético.

Téngase presente que tales dinámicas constituyen un proceso de comunicación donde unos se autoperciben con los otros y que, como en el deporte, esto se transcribe a la acción; el asunto no se queda solo en la socialización o en el asumir roles, sino también se gesta realidad. El actor, lejos de ser estático, es dinámico y a su vez tiene capacidad de interpretar el mundo social; en este punto piénsese, por ejemplo, en la Coalición Costa Rica, grupo de personas convocado por redes sociales que, de cara a la segunda votación del proceso electoral presidencial de 2018, generó una movilización que tuvo episodios de apropiación del espacio urbano (reunión en la Plaza Roosevelt el 10 de febrero de ese año).

Pese a esas "apariciones en público", lo cierto es que la interacción en la que se incorporan valores de una causa social común al tiempo que se aplaudía la individualidad y creatividad de cada quien (una suerte de "yo"5)

\footnotetext{
${ }^{4}$ Marcha de la conmemoración del 8 de marzo "Día Internacional de la Mujer".

${ }^{5}$ Algunos de los principales conceptos del interaccionismo simbólico (que permiten comprender la idea que se pretende exponer), tomando de base a Ritzer (1993), son: El self ha de entenderse como la capacidad de considerarse a uno mismo como objeto que se construye a partir del proceso social de comunicación con otros y, también, con base en las experiencias sociales en general. El camino para su desarrollo es la reflexión o la capacidad de ponerse inconscientemente en el lugar de los otros y actuar como ellos lo harían (también, va de evaluarse a sí mismo). Es un concepto social habida cuenta que, cuando se ha formado, se manifiesta -aunque en menor intensidad- en actividades habituales o fisiológicas, siendo las dinámicas sociales los espacios para su exposición.

El self está formado por el Yo y por el Mí. El Yo es la respuesta inmediata de un individuo a otro, lo creativo, lo imprevisible y lo incalculable; es eso que nos permite introducir el cambio social. Este componente debe tomarse en cuenta por los siguientes aspectos: a) es fuente de innovación social; b) en él se encuentran los valores más importantes; c) constituye la realización del Self; y d) es un rasgo de las sociedades modernas (en las primitivas hay un predominio del $M i ́)$.

El Mí, en cambio, es la adopción del otro generalizado por parte del sujeto. "El mí permite al individuo vivir cómodamente en el mundo social, mientras el yo hace posible el cambio de la sociedad" (Ritzer, 1993, p. 235).
} 


\section{DERECHO ELECTORAL}

se dio, primordialmente, por intermedio de Facebook. En concreto, en los medios de comunicación se hacía ver que:

Hasta ahora el grupo de Coalición Costa Rica en Facebook cuenta con más de 274 mil miembros, 8 mil publicaciones de ellos mismos y más de 200 mil comentarios. La página oficial en Facebook también acumula 23 mil "Me Gusta". Los fundadores indicaron que cerca de $\mathbf{9 . 8 0 0}$ personas se han inscrito vía web para colaborar antes y durante el balotaje del 1 de abril. (Alvarado, 2018).

Como lo señala Mead (1934), en la interacción se dan problemas de la acción interpersonal: en situaciones sociales, el propio actor es una fuente de estímulos para su compañero; por ello, el individuo debe prestar atención a sus propias formas de actuar, pues estas provocan reacciones en su interlocutor $y$, por tanto, se convierten en condiciones para continuar con sus propias acciones (Joas,1991). De esa suerte, en las redes sociales si el perfil es de un grupo, como Coalición Costa Rica (pero también tratándose de un partido político) la acción debe ser reposada para lograr una respuesta adecuada (adscripción al colectivo) que, a su vez, permita continuar con la lógica prevista.

Si se trata de un perfil personal, la dinámica está acentuada en procesos de corte más creativo ("yo"); existe un ámbito libérrimo para dar la opinión, pero esta -a su vez- va a despertar reacciones en una comunidad amplia. Inclusive, la posibilidad de ejercer tal libertad de expresión está condicionada por el sentir que se tenga del interlocutor. Piénsese en la reacción por el tuit del Ministro de Educación Pública -Edgar Mora Altamirano- ${ }^{6}$ en relación con el suicidio; el contenido del mensaje no calzó con la expectativa simbólica que se tiene del jerarca de esa cartera ministerial y por ende causó escozor. En similar sentido, evóquese el mensaje publicado por un parlamentario en el que, echando mano de una desafortunada metáfora acerca de la posesión de un "ropero muy grande"7,

\footnotetext{
6 El tuit escrito por el jerarca de Educación Pública decía: "Suicidarse es una manera de decir la verdad, posiblemente la más vehemente de todas". Ver nota del periódico La Nación "Ministro de Educación se disculpa por tuit sobre suicidio"; edición digital del 9 de junio de 2018. Disponible en: https://www.nacion.com/elpais/educacion/ministro-de-educacion-se-disculpa-por-tuit-sobre/OLDKHAFK7FDDBM6WPFAPIER7IY/story/

7 El diputado a la Asamblea Legislativa (2018-2022) Pablo Heriberto Abarca, de la fracción del partido Unidad Social Cristiana (PUSC), escribió "El ropero Pate es bien grande!!!" en alusión -supuestamente despectiva- al entrenador del equipo contrario al suyo y al "armario" o "closet" como metáfora para los homosexuales que no han hecho pública su orientación sexual. Ver nota del diario digital CRHOY.com "Diputado Pablo Abarca: "El ropero
} 


\section{DERECHO ELECTORAL}

se cuestionaban decisiones de un entrenador de fútbol, tomadas durante un partido.

Similares a lo anterior son los insultos o los comentarios mordaces contra agrupaciones o candidatos específicos que pueden ser replicados al punto de generar un estímulo negativo en perjuicio de la imagen y, a la postre, del caudal electoral. Ese proceso, en el medio virtual, despierta el fenómeno "bola de nieve" con la agravante de que, en no pocas ocasiones, la imposibilidad de determinar de dónde provino el impulso definitorio de desenlaces no previstos. El cúmulo de interacciones es tal y las expectativas de compartir cierto tipo de pautas resulta tan fuerte que puede -inclusodar al traste con una postulación. De nuevo, esto lleva a una valoración de uno mismo y del otro, de mi comportamiento frente al otro, del yo y del mí, donde el "yo es la reacción del organismo a las actitudes del otro y el mí es la serie de actitudes organizadas de los otros que adopta uno mismo" (Perlo, 2006).

Ciertamente, la corriente interaccionista de Mead es una de las más extendidas y por ello se viene desarrollando el tópico a partir de sus referentes; empero, es oportuno el abordaje de algunas perspectivas de Blumer (1992), por su relación con las redes sociales. Ese teórico acentúa su producción y ubica como principal objeto de estudio a los procesos de interacción (acción social que se caracteriza por una orientación inmediatamente recíproca); así, subraya el carácter simbólico de la acción social para generar un particular concepto de interacción. Un caso prototípico es el de las relaciones sociales en las que la acción no adopta forma de mera traducción de reglas fijas en acciones, sino que las definiciones de las relaciones son propuestas y establecidas colectivamente (Joas,1991). Lo anterior desemboca en que las relaciones sociales no quedan establecidas de manera perdurable sino, antes bien, se comportan de forma abierta y sometidas al continuo reconocimiento por parte de los miembros de la comunidad.

Las redes sociales tienen políticas de uso que, como usuarios, se deben seguir; sin embargo, es la interacción cotidiana la que modula cómo han de comportarse los cibernautas y cuáles han de ser los niveles de tolerancia de los contenidos que se "cuelgan", de forma tal que la relación fragua las

de Paté es bien grande", edición del 6 de abril de 2019. Disponible en: https://www.crhoy.com/nacionales/diputado-pablo-abarca-el-ropero-pate-es-bien-grande/ 


\section{DERECHO ELECTORAL}

acciones y sus reglas, elementos prescriptivos que se mantienen vivos y con posibilidades de variar según las dinámicas internas de la red.

En la teoría de interacción simbólica de Blumer (1992) se concibe al emisor y al receptor como individuos activos y libres que, por la interacción social con los otros participantes, conforman los significados que interpretan la realidad social (¿virtual?), lo cual resalta la importancia del contexto cultural que afecta a los actores: las lógicas de las redes sociales generan tendencias y símbolos significativos que, a su vez, dan origen a realidades particulares, incluso cuando estas no tienen mayores referentes empíricos o estos no se corresponden con lo sostenido. Para mayor claridad piénsese en las fake news (noticias falsas) que hallan asidero en un contexto cultural mediado por la inmediatez y la falta de rigor: tantas veces se repita o cuantos más likes se tengan se da una mayor sensación de veracidad, apariencia que condiciona el comportamiento del sujeto, quien actuará como si el bulo fuese verdad. Por tal motivo, resulta tan seductor tener, en los cuarteles de campaña, equipos monitoreando redes $y$, en algunas ocasiones, hasta personas contratadas para diseminar alguna que otra imprecisión.

En pocas palabras: el actor se ve influido de forma individual por el valor que se transmite a través de las redes. Además, ese sujeto está expuesto a una dinámica de elección y de toma de posición frente a los valores y modelos estereotipados por la misma interacción en su contexto social habitual (Acuña, 2011).

En redes sociales se han acuñado palabras, signos, símbolos y abreviaturas que se han popularizado por su uso constante, como los acrónimos LOL (Laughing out loud $=$ reírse en voz alta), YOLO (you only live once = solo vives una vez), entre otras; tal fenómeno genera nuevos signos significantes inexplorados. Para el momento en que el interaccionismo simbólico tuvo su auge, las dinámicas en esos espacios virtuales era insospechada.

Pese a ello, tal contexto cibernético es un rico campo para explorar cómo las interacciones de los sujetos van desde las respuestas típicas a expectativas simbólicas (cómo comportarse frente a un "me encanta" o cuál es su sentido en esa lógica nueva de interrelación social), hasta la impronta creativa que cada quien dará a sus posteos. Sin ir más lejos, el uso de emojis para expresar sentimientos se ha popularizado: son significados y significantes que participan del proceso de interpretación de la realidad 


\section{DERECHO ELECTORAL}

social y resumen cómo se mueven los actores entre las pautas culturales de las redes sociales.

El self, siempre social, en estas nuevas dinámicas va, entonces, de analizar un "mí" que permite desenvolvernos según pautas culturales de la web, al tiempo que hay un "yo" con capacidad creadora, pero siempre dentro de ese buen hacer en los perfiles. Tanto dentro como fuera de la computadora, el potencial individual está mediado por la aceptación posicionada en un espacio de respuestas que, como grupo humano, hemos adoptado en la forma de "mí"; o sea, la sociedad. En esos ires y venires, la competencia por cargos de elección instrumentaliza las plataformas web para lograr su cometido (el triunfo) y, en ese tanto, debe ser precisa en leer cuáles son los marcos de plausibilidad e interacción para, con éxito, formar parte de las dinámicas sin transgredirlas: dar de qué hablar para estar presente en las consciencias de los electores sin generar polémicas que, más bien, resten el apoyo. Lo complicado de esto es que un paso en falso -a pocos días del evento comicial- puede invertir intenciones de voto que, en casos extremos, podrían variar los resultados.

En la introducción se decía que este primer apartado lo era para comprender un poco cómo se daban (funcionaban) las dinámicas en redes, pero también para sugerir cuáles atributos les dan ese sex-appeal que nos inclina a su uso y, puntualmente, a su desarrollo en los momentos clave de los eventos político-electorales.

Hace no tanto tiempo, la exigencia social era que el individuo supiera diferenciar entre lo público y lo privado. Frases populares como "la ropa sucia se lava en casa" son reflejo de una cultura que justipreciaba positivamente un ámbito íntimo (como el de las relacionas familiares del refrán), ajeno al conocimiento de terceros. Precisamente, en el ámbito jurídico, el Tribunal Constitucional Federal alemán fue enfático, en su célebre sentencia sobre la "Ley del Censo" (resolución de diciembre de 1983), al precisar que existen tres esferas de los sujetos: la pública, la privada y la íntima, donde esta última es un arcano reducto al que nadie -salvo el propio individuo- tiene acceso. En ese espacio tan propio como protegido se encuentran informaciones como la orientación sexual y, de gran relevancia para estas líneas, la ideología u opinión política.

Sin embargo, la aparición de las redes y sus productos asociados han ido desdibujando esa línea, dejando de ser tres esferas para convertirse en una sola: el sujeto virtual es el sujeto real, quien se construye y deconstruye a 


\section{DERECHO ELECTORAL}

fuerza de likes, me divierte, me enoja, me entristece; su autoestima, más que en test o entrevistas psicológicas, se mide en seguidores. En palabras de Sibila (2008, pp. 27-28):

En este siglo XXI que está comenzando, en cambio, se convoca, a las personalidades para que se muestren. La privatización de los espacios públicos es la otra cara de una creciente publicitación de lo privado, una sacudida capaz de hacer tambalear aquella diferenciación de ámbitos antes fundamental.

Desde esa perspectiva, como ahora las personas construyen su subjetividad en la interacción en redes, resulta trascendental exhibirse, contarlo todo, mostrarlo todo; se da una preponderancia al contenido personal, íntimo, historias que cuentan lo que, hasta hace menos de dos décadas, no se contaría. Como lo resume la citada antropóloga argentina:

Millones de usuarios de todo el planeta -gente "común", precisamente como usted o yo- se han apropiado de las diversas herramientas disponibles on-line, que no cesan de surgir y expandirse, y las utilizan para exponer públicamente su Intimidad. Así es como se ha desencadenado un verdadero festival de "vidas privadas", que se ofrecen impúdicamente ante los ojos del mundo entero. Las confesiones diarias están ahí, en palabras e imágenes, a disposición de quien quiera husmear; basta apenas con hacer clic. (Sibila, 2008, p. 32).

Así las cosas, como eso es lo que hacemos, un show del yo (Sibila, 2008), demandamos lo mismo de nuestros interlocutores $y$, en ese tanto, quien desee postularse a un cargo de elección popular debe tener presente que no tendrá más ese ámbito íntimo vedado a sus votantes; por el contrario, debe hacerse público, situación que si bien no es nueva (desde hace varias décadas entendemos como derecho el poder escudriñar en la vida privada de nuestros gobernantes), lo cierto es que se ve reforzada por la relativa sencillez con la que se puede compartir la información. El candidato que no tenga un perfil en el que exponga su vida y milagros es porque huye de la transparencia, sin que el colectivo pueda pensar en otras explicaciones tan válidas como el "no quiero tener redes sociales, así como nunca he querido tener mascotas".

Entonces, el uso de las redes sociales se vuelve necesario en tanto es un símbolo de cercanía, horizontalidad y diafanidad, características deseables 


\section{DERECHO ELECTORAL}

en cualquier persona que aspire a tener un cargo en la estructura del Estado. El candidato se va construyendo en la interacción y, por paradójico que parezca, pese al conocimiento generalizado de que, por lo común, son terceros los que manejan las cuentas y perfiles (community manager), la gente suele identificarse al punto de pensar que, en efecto, interactúa con el propio postulante.

De hecho, eso se podría explicar a partir del relativamente nuevo deseo por abandonar la ficción y creer en los "yo real" (Sibila, 2008). Como signo de la cultura contemporánea se ha dado una inclinación por las biografías, relatos que muestran la "parte humana" de sujetos de relevancia para el conglomerado social, reportajes que tienen que ver con acciones individuales para la superación de obstáculos, entre otros. Actualmente, "proliferan las narrativas biográficas, la espectacularización de la intimidad y las exploraciones artísticas de todas las aristas del yo" (Sibila, 2008, pp. 244-245).

En ese orden de ideas, toma sentido la demanda por perfiles en los que los candidatos se muestren como personas "comunes", capaces de compartir sus vicisitudes, evidenciando el cumplimiento de roles y tareas cotidianas, departiendo con vecinos $y$, de gran relevancia, exhibiéndose a sí mismos en tiempo real: los live son poderosas herramientas para dar a conocer el instante que se está viviendo, al tiempo que se permite una interacción inmediata.

Precisamente, esa fue una de las estrategias utilizadas por el candidato del partido Acción Ciudadana (PAC), Carlos Alvarado Quesada, quien finalmente resultó electo presidente de la República. De ello dan cuenta las notas periodísticas, así como el propio vencedor de las justas electorales de 2018.

En el diario digital elpais.com, luego del triunfo de Alvarado, se informó:

De la campaña se recuerda un Facebook Live (transmisión en directo a través de la red social) hecho por el candidato en paralelo a un debate televisivo al que no lo invitaron, cuando las encuestas no le daban opciones. También, haber compartido el número de teléfono para que le enviaran consultas por audios o la foto posterior al debate final en que el candidato y su esposa se ven relajados bebiendo una cerveza en el sillón de la pequeña sala de su casa, en una zona exclusiva llamada Lindora al oeste de San José. (Murillo, 2018, párr. 8). 


\section{DERECHO EIECTORAL}

Como puede observarse, hay una búsqueda por la cercanía (incluso se da el número de móvil), al tiempo que se comparten momentos "íntimos" (departir con la esposa en el hogar) y se muestra un individuo que tiene prácticas comunes a sus eventuales electores: beber una cerveza al final de una jornada de trabajo para relajarse.

Esa intención de sacar provecho a los puentes que permiten construir las redes sociales no solo es presunta, sino que fue expresamente reconocida por el otrora candidato:

Hicimos una campaña cercana a la gente, en la casa, en las calles, por las redes. Este fue nuestro último Facebook Live como candidato. Gracias por corresponder esa cercanía, nos vemos pronto

En suma, se puede afirmar que el uso de redes se da para acercar a la ciudadanía con el candidato y a la inversa; en el primer supuesto, las personas siguen a los contendientes, les hacen preguntas, comentan sus publicaciones $y$, en suma, se sienten verdaderos actores de la dinámica electiva y no simples observadores pasivos a los que se les pide un voto irreflexivo.

Tratándose de quien busca el favor de sus conciudadanos, debe subrayarse la idoneidad de las redes como vehículo para la transmisión de mensajes sencillos, para mostrar calidez y horizontalidad, para dar una impresión de apertura $y$, de gran relevancia, para presentarse como un humano demasiado humano ${ }^{8}$.

El efecto amplificador de las redes es otro de los incentivos para su uso. En enero del 2018, Facebook registró cerca de 2167 millones de usuarios activos en un mes; YouTube tuvo más de 1500 millones de efectivos

\footnotetext{
${ }^{8}$ Es claro que esa también es una labor del equipo de campaña: el candidato no solo es, sino se construye. Las redes dan extraordinarios espacios para generar un individuo más allá del individuo, que cumpla con los parámetros de deseabilidad que maneja el colectivo.
} 


\section{DERECHO ELECTORAL}

cibernautas en esa misma unidad temporal; Whatsapp reportó cifras superiores a los 1300 millones de personas enviando y recibiendo mensajes en treinta días; e Instagram, en uno de los doceavos del año, cuantificó más de 800 millones usando su plataforma (Mejía, 2018). Estas cifras muestran cómo las redes sociales han tenido un crecimiento exponencial, ya que, por ejemplo, en 2009 Facebook contaba con 802 millones de usuarios (Ayala, 2014), cantidad que no representa -ni siquiera- a la mitad de quienes, según los citados datos de 2018, ingresa a ese sitio durante un mes.

Las campañas buscan hacer llegar el mensaje político a la mayor cantidad de personas posible, circunstancia que si puede lograrse a bajo costo traerá consigo mejores rendimientos para las agrupaciones. Las redes sociales justamente permiten eso: una persona (o grupo reducido de ellas) puede generar contenidos en el perfil del candidato que luego, con un solo clic en "publicar", puede alcanzar a millares de votantes, efecto que por vías tradicionales demoraría mucho o, si se utilizaran medios de alcance masivo como la televisión, costaría una cantidad considerable de dinero.

Más de doscientas veinte mil personas siguen en Facebook la página de Fabricio Alvarado Muñoz, candidato que en abril de 2018 disputó la presidencia -en segunda ronda- con el entonces postulante del PAC, esa cifra resulta considerable si se tiene en cuenta, solo para efectos de dimensionar el peso de tales seguidores, que en la primera ronda la distancia entre el partido más votado (Restauración Nacional) y el segundo lugar (Acción Ciudadana) fue de poco más de setenta mil votos ${ }^{9}$. Ciertamente, en los seguidores podrían estarse contando personas no habilitadas para ejercer el voto (menores de edad y extranjeros no naturalizados); no obstante, tal comparación lo es solo con fines ilustrativos: evidenciar que una publicación en el muro del otrora competidor (que no tiene mayor costo) puede llegar a un número de personas incluso superior a aquel que se requirió para ingresar en el ballotage.

Por último, no puede dejarse de lado la sensación de compañía que se tiene en las redes sociales; como si se tratara de uno de los mejores retratos del sesgo de autoconfirmación, los muros evidencian cómo, en casi la totalidad de los casos, las personas convierten sus perfiles en burbujas epistémicas:

\footnotetext{
${ }^{9}$ Ver resoluciones del Tribunal Supremo de Elecciones $n .^{\circ s} 1265-E 11-2018$ de las 11:00 horas del $1 .^{\circ}$ de marzo de 2018 y $970-E 11-2018$ de las 12:10 horas del 15 de febrero de 2018.
} 


\section{DERECHO ELECTORAL}

normalmente acepto como amigo a quien tiene una vertiente de pensamiento muy similar a la mía. Es difícil que alguien admita en su círculo a un sujeto que le critica constantemente o que su visión de mundo se distancia palpablemente de la suya.

Esa particularidad genera una percepción de que "el mundo" entero está conmigo y mi opinión es la del grueso de la población; al lanzar un cuestionamiento en contra de un candidato (o alguna de sus propuestas) me veo respaldado por innumerables likes y comentarios favorables a mi comentario detractor. En la acera contraria sucede algo similar, pues los adláteres de la tendencia en crítica se enardecerán, pero siempre en compañía (la virtual), en contra de quienes la han emprendido contra su figura política. Entonces, el desenfado se da en razón de que el miedo al aislamiento se ha perdido y con él cualquier cortapisa al mensaje.

Neumann (1995), de la mano de la célebre frase de Tocqueville "temían el aislamiento más que el error" (1989), señala cómo los individuos, aun teniendo la verdad de su lado, suelen temer el extrañamiento de sus congéneres, de forma tal que son propensos a cambiar sus opiniones para adecuarlas a las de su grupo de referencia. En las redes, esa "soledad" no está presente y el riesgo es mucho menor que en la vida cotidiana, pues de antemano se cuenta con un grupo más grande o más chico de personas que respaldarán la postura. Eso, junto con otras variables como el anonimato o la ligereza en el manejo de datos (tácitamente autorizada en esos entornos virtuales), permite envalentonar al cibernauta para que critique, cuestione e incluso amenace al candidato que, como se dijo, siente frente a sí, en un plano de horizontalidad.

En ese sentido, se clama por ejercicios "democráticos" en los que existan canales de comunicación y de rendición de cuentas directos, se empieza a creer que las redes son un espacio legítimo para echar a andar la dinámica institucional punitiva. Varios fueron los momentos, en el proceso electoral 2018 , en los que la ciudadanía pretendía que, por intermedio de denuncias en redes sociales, el organismo electoral investigara actos que en su criterio eran contrarios a las normas; se argumentaba que ya eran reiterados los comentarios en los muros y que las pruebas estaban en esas mismas interacciones ${ }^{10}$.

\footnotetext{
10 Sobre este tema resulta ilustrativo que, en la demanda de nulidad atendida por sentencia n. ${ }^{\circ}$ 2152-E4-2018 de las 13:00 horas del 10 de abril de 2018, el gestionante solicitó la nulidad de la Segunda Ronda alegando, entre
} 


\section{DERECHO EIECTORAL}

Para decirlo en breve: la utilización de redes sociales en las dinámicas comiciales por parte de la ciudadanía es vista, en cierto modo, como la herramienta para desacralizar las figuras y los figurones, para mostrar una "fuerza" del colectivo que es soberano. En fin, es el acto -justificado por los usuarios- mediante el cual se controla a los otros de esa "casta corrompida" que aspira a cargos de gobierno. Es una forma de legitimación que encuentra asidero en los discursos antipolítica.

\section{Redes sociales en la jurisprudencia del Organismo electoral COSTARRICENSE}

Para una mayor claridad expositiva, en este apartado se ha optado por presentar temáticamente los principales pronunciamientos de la autoridad electoral en punto a las redes sociales y el espacio cibernético.

\section{a) INTERNET: FUENTE DE INFORMACIÓN Y MEDIO DE COMUNICACIÓN}

Desde el 2009, el TSE hizo una importante diferenciación que, si bien no profundizó en las redes sociales, sí precisó cómo había que entender Internet en su dimensión de espacio virtual donde se desarrollan una multiplicidad de dinámicas. Esa precisión supuso aclarar que la red funciona como una fuente de información pero, también, como un medio de comunicación ${ }^{11}$.

Para la legislación costarricense, tener en cuenta lo anterior es altamente importante porque, por ejemplo, existe un periodo en el que no se puede hacer publicidad proselitista ${ }^{12}$, situación restrictiva que se torna excepcional en tanto el marco normativo patrio establece que los partidos políticos pueden hacer propaganda en cualquier tiempo (artículo 136 del Código Electoral); en otros términos, no se necesita estar en período de campaña

\footnotetext{
otros, "la imposibilidad de presumir el actuar de buena fe de las juntas receptoras de votos en tanto existen múltiples denuncias en redes sociales".

${ }^{11}$ La resolución $n .^{\circ}$ 0978-E8-2009 de las 11:45 horas del 19 de febrero de 2009 debe considerarse, en simultáneo, la sentencia fundadora (es la primigenia) y la estructurante (vertebra la discusión y da pautas orientativas) acerca de Internet en su doble dimensión: fuente de información y medio de comunicación.

12 Según el artículo 136 del Código Electoral: "Todo partido político se abstendrá de difundir propaganda política en medios de comunicación colectiva del 16 de diciembre al 1.0 de enero, ambos inclusive, inmediatamente anteriores al día de las elecciones".
} 


\section{DERECHO EIECTORAL}

para que las agrupaciones puedan discutir sus ejes programáticos o hacer propaganda para procesos electorales o comicios futuros.

Como fuente de información, el Tribunal comprende Internet cuando el usuario tiene que llevar a cabo una conducta activa para tener acceso al contenido. Entonces, las páginas de los partidos políticos, perfiles de Facebook, canales de YouTube, etc. se entienden dentro de esa modalidad. Se podría cuestionar: mi muro se actualiza automáticamente cuando alguien publica en el suyo alguna información; sí, mas usted tuvo que llevar a cabo una conducta activa para que eso ocurra. Por ello, cuando se entiende el espacio virtual como fuente informativa, los periodos de veda no les alcanzan a las referidas plataformas; debe insistirse: lo que se establece en la normativa es una restricción para difundir en "medios de comunicación", durante lapsos específicos.

Ahora bien, aplicando la referida interpretación a las redes sociales, será considerado propaganda aquello que suponga publicidad pagada, como pueden serlo banners en Facebook, pues ahí existe una invasión de la información en nuestros monitores. O sea, estamos en el chat o revisando el muro y -de un pronto a otro- se despliega algo que nosotros no queremos o no habíamos previsto; ese escenario es asemejable a que usted esté viendo la novela y -de repente- un spot publicitario salte en medio de la pausa del programa.

\section{b) REDES SOCIALES Y LA VEDA PARA DIVULGAR INFORMACIÓN GUBERNAMENTAL}

Como una garantía de equidad en la contienda, el legislador costarricense prohibió que, durante el período que va desde la convocatoria a una elección nacional y hasta el día de celebración de los comicios, "instituciones del Poder Ejecutivo, de la administración descentralizada y de las empresas del Estado, a las alcaldías y los concejos municipales" difundan, mediante cualquier medio de comunicación, información relativa a sus logros, obra pública realizada y bondades de la gestión de sus jerarquías (ordinal 142 del Código Electoral). 


\section{DERECHO EIECTORAL}

Esa restricción, que no aplica para procesos electorales municipales ${ }^{13}$, no impide que las instituciones públicas utilicen sus redes sociales para difundir sus actividades y giro propio, ya que, como se vio en el acápite anterior, ahí tales plataformas funcionarían como fuente de información. Eso sí, está vedado pagar publicidad en tales redes (entre otras, ver resoluciones n. os 6429-E7-2010, 0063-E7-2010, 5491-E7-2009, 5490-E7-2009 y 2694-E-2006).

Puntualmente, en la sentencia n. ${ }^{\circ}$ 4418-E8-2013 se resume el tópico en comentario al indicarse:

En el caso de la información para publicar en redes sociales o blogs este Tribunal ha señalado que la veda establecida no discrimina entre medios de comunicación, así que debe entenderse que prohíbe las informaciones publicitarias que se difundan por los mecanismos tradicionales (televisión, radio o prensa escrita, entre otras) o no tradicionales, como lo es Internet. En este último caso, para considerarse "publicitaria" a efectos de la prohibición, además de ser onerosa debe ir dirigida al receptor mediante la imposición de un mensaje no procurado o deseado por él (instantáneo o espontáneo). Por ello, la información que se encuentra a disposición del explorador de Internet pero que requiere, para su acceso, una búsqueda activa y voluntaria del receptor ("Facebook", "Youtube", "Twitter", páginas web) no configura publicidad prohibida y se considera una actividad meramente informativa enmarcada en el ámbito de la libertad de expresión, siempre y cuando no medie la contratación y pago de espacios publicitarios típicos de las redes sociales (v.s., los denominados "banners"). [subrayado del original]

\section{c) Redes sociales y La BeligeranCia política}

El constituyente previó, como una de las garantías del sufragio, la imparcialidad de las autoridades de gobierno (artículo 95, inciso 3); para operacionalizar ese canon, el legislador ha desarrollado un régimen de prohibición a la participación política de los funcionarios públicos. Por una

\footnotetext{
${ }^{13}$ En la sentencia n. ${ }^{\circ}$ 5027-E8-2010 de las 13:00 horas del 26 de julio de 2010, el TSE dispuso: "Se interpreta oficiosamente el artículo 142 del Código Electoral en el sentido de que la veda publicitaria ahí establecida no aplica para las elecciones municipales".
} 


\section{DERECHO EIECTORAL}

parte, se tiene la restricción genérica que alcanza a todas las personas que sirven al Estado y consiste en no dedicarse, durante la jornada laboral, a discusiones político-electorales ni utilizar el cargo para beneficiar o perjudicar a una agrupación (párrafo primero del artículo 146 del Código Electoral).

De otra parte, existe una limitación de mayor intensidad que aplica a ciertos funcionarios (normalmente los de mayor rango) y supone que no es posible realizar ningún acto político-partidista, salvo emitir el voto en una elección convocada por la autoridad electoral (párrafo segundo del referido ordinal 146).

Ahora bien, en lo relativo a las redes sociales y las prohibiciones expuestas, la magistratura electoral ha determinado que:

...el uso de las redes sociales (dando "me gusta" en el perfil de Facebook, siendo amigo en Facebook o seguidor en el perfil de Twitter) por parte de [...] los funcionarios con prohibición absoluta, no está prohibido ni configura el ilícito de beligerancia política previsto en el artículo 146 del Código Electoral, siempre que, como parte de dicho uso, el funcionario público no consigne adicionalmente expresiones que puedan interpretarse, inequívocamente, como actos de ostentación de simpatía partidaria, ya que esa conducta sí estaría prohibida. (sentencia n. ${ }^{\circ}$ 2575-E8-2014) ${ }^{14}$.

En ese precedente se determinó, también, que ser amigo en Facebook o seguidor en Twitter no es una conducta constitutiva del ilícito electoral previsto en el numeral 146 antes comentado.

De otra parte, en lo que atañe a la prohibición genérica, es claro que los servidores públicos afectos a ella pueden hacer libre uso de sus redes sociales -incluso haciendo actos de ostentación partidaria- siempre que eso "no ocurra durante su jornada laboral ni mediando el uso de recursos públicos que, en razón de su cargo, tengan a su disposición" (resolución n. $\left.{ }^{\circ} 8080-E 8-2017\right)$.

\footnotetext{
${ }^{14}$ Conviene aclarar que esta postura no es del todo pacífica, pues -en un voto salvado- el entonces magistrado propietario pro tempore Brenes Villalobos indicó que expresiones como like, me gusta, me encanta u otras similares sí son muestra de simpatía partidaria y, consecuentemente, están vedadas a funcionarios que se encuentren sujetos al régimen de prohibición absoluta (ver resolución 8080-E8-2017).
} 


\section{DERECHO ELECTORAL}

\section{d) REDES SOCIALES Y LA PUBLICIDAD DE ESTADOS FINANCIEROS PARTIDARIOS}

Derivado del principio de transparencia, el Código Electoral exige que las agrupaciones políticas, anualmente, publiquen -en un diario de circulación nacional- un estado auditado de sus finanzas, incluida la lista de sus contribuyentes o donantes (numeral 135).

Ante ello, un partido político consultó al TSE si tal obligación se podría cumplir con subir - a sus redes sociales- la información financiera a la que alude la legislación; sin embargo, en la sentencia n. ${ }^{\circ}$ 7616-E8-2016 se clarificó que:

...no es jurídicamente admisible, en orden a dar debido cumplimiento a lo estipulado en el artículo 135 del Código Electoral, que los partidos políticos hagan la publicación anual de sus estados financieros auditados $y$ el reporte de sus contribuciones o donaciones en su sitio web o perfil de Facebook oficial.

Sin perjuicio de lo anterior, se hace ver que resulta válido realizar la publicación en comentario en la versión digital de un medio de comunicación (pronunciamiento de las 15:30 horas del 5 de diciembre de 2014, dado en las diligencias que se tramitaron en el expediente $n .^{\circ} 245-S-2014$ ).

\section{e) BLoqueo de SEguidores en REDES SOCIALES DE CANDIDATOS}

En el proceso electoral nacional de 2018, un candidato a la Presidencia de la República bloqueó, de su cuenta de Twitter, a un ciudadano que constantemente criticaba sus manifestaciones y sus propuestas. Como consecuencia de ello, el elector planteó una gestión de amparo electoral en aras de restablecer sus derechos de libertad de expresión y de acceso a la información que, por la referida acción del postulante, consideró transgredidos.

Por su parte, en la sentencia que atendió el reclamo, la autoridad electoral resolvió:

Bajo el contexto de la llamada sociedad de la información o más recientemente denominada era informacional, las agrupaciones políticas han utilizado las diversas plataformas digitales (páginas web o redes sociales) para crear cuentas oficiales y situar en ellas 


\section{DERECHO EIECTORAL}

datos y mensajes político-electorales de su interés. Sin perjuicio de lo anterior, cabe la posibilidad de que un integrante de un partido entre ellos, su candidato a la Presidencia- publique o "cuelgue" diversa información partidaria en un perfil o cuenta personal, lo que no implica que esa plataforma, por esa sola circunstancia, deba considerarse como pública u oficial del partido.

En el caso de las publicaciones realizadas en una cuenta personal, los datos divulgados en esas plataformas, aun cuando estén relacionados con la agenda política de la agrupación, no tienen la virtud de convertir en público el perfil utilizado por el candidato; es decir, su uso y administración continúan siendo de índole privada, por lo que el Estado deberá abstenerse de ejecutar cualquier acción que limite la autonomía de sus propietarios.

En otros términos, no puede el Estado obligar a quienes se postulan a un cargo de elección popular a gestionar sus perfiles de una manera determinada (aceptar, bloquear, desbloquear o eliminar seguidores, publicaciones, comentarios, entre otros), pues ello supone una restricción irrazonable a la autonomía de la voluntad de la persona y una extralimitación de las competencias de organización, fiscalización y vigilancia de los procesos comiciales, conferidas a este Órgano Electoral. (Resolución n. 3252-E1-2018).

Como puede verse, parte importante de la ratio decidendi consiste en que el perfil del candidato era personal, por lo que no se le podía obligar a que tuviera interrelaciones con sujetos específicos; sin embargo, en sentido contrario, puede entenderse que si se trata de cuentas oficiales de la agrupación política, la acción de bloquear a un ciudadano no resultaría legítima $y$, por ende, supondría una afrenta a los derechos políticoelectorales del elector excluido.

\section{Redes sociales y procesos electivos: posibles respuestas}

La utilización de las redes sociales en los procesos electivos ha sido foco de atención en no pocos lugares alrededor del mundo, en lo que a legislación se refiere. En Alemania, país pionero en la temática, se aprobó una ley en 2017; el parlamento teutón determinó que plataformas de Internet, con fines de lucro, que divulguen cualquier tipo de contenido y sumen más de dos millones de usuarios deben atender los reclamos por noticias falsas y 


\section{DERECHO EIECTORAL}

eliminar, en el plazo de veinticuatro horas, contenidos claramente ilícitos. Si la denuncia supone alguna verificación de información compleja, entonces el plazo para remover el texto cuestionado es de siete días.

En el diseño normativo alemán, el parámetro para determinar la legitimidad de las publicaciones viene dado por el Código Penal, ya que la ley hace un reenvío normativo a ese instrumento regulatorio para llenar el concepto indeterminado de "contenidos ilícitos". Sin embargo, la apertura de las formulaciones no suele cerrarse del todo y las empresas, con tal de evitar multas que pueden llegar hasta los cincuenta millones de euros, hacen una revisión propensa a restringir los contenidos $y$, por ende, contraria a la libertad de expresión (Weidenslaufer, 2019).

En similar sentido, Francia contaba con leyes que, por su redacción amplia, permitían sancionar la difusión de noticias falsas (con multa y con pena privativa de libertad, según fuera el caso); sin perjuicio de ello, a finales de diciembre de 2018, se aprobó una ley que específicamente refiere al tratamiento de noticias falsas en el marco de procesos electorales.

En concreto, en los artículos L. 163-1. y L. 163-2.-I. de la ley $n{ }^{\circ}$ 2018-1202 de 22 de diciembre de 2018 (relativa a la lucha contra la manipulación de la información ${ }^{15}$ ) se estableció la obligación de los medios y plataformas digitales de transparentar quiénes y a qué precio están divulgando las informaciones acerca del proceso electoral; además, se creó un procedimiento expedito (puede tardar aproximadamente cinco días contando la fase de apelación) para que los jueces puedan retirar datos engañosos o inexactos que hubieran sido difundidos de manera deliberada, artificial o automatizada y masiva. A lo anterior se suma la posibilidad de imponer prisión o multa a los responsables.

Contrario a esa tendencia punitiva, el Consejo de Europa, ante el complejo panorama político (lograr unanimidad para la aprobación de leyes en todo el espacio), ha optado por acciones que favorecen la detección temprana de noticias falsas y la preparación de manuales de buenas prácticas en ese ámbito ${ }^{16}$.

15 El texto de esta ley puede consultarse en: https://www.legifrance.gouv.fr/eli/loi/2018/12/ 22/MICX1808389L/jo/texte

${ }^{16}$ Para un resumen de las acciones de la Unión Europea, ver el comunicado de prensa de la Comisión Europea denominado "Combatir la desinformación en línea: La Comisión propone un Código de Buenas Prácticas para toda la UE" del 26 de abril de 2018 que a su vez incorpora vínculos a documentos sobre el tema en desarrollo. Disponible en: europa.eu/rapid/press-release_IP-18-3370_es.pdf 


\section{DERECHO ELECTORAL}

De otra parte, en naciones americanas como México y Panamá las autoridades electorales han impulsado acuerdos -entre candidatos y con los representantes de las principales redes sociales- para combatir las noticias falsas. En el caso panameño se aprobó el Pacto Ético Digital, cuyos suscriptores (organismo electoral, partidos políticos, candidatos y ciudadanía en general) se comprometen a "no utilizar campañas sucias como elementos de falso debate; no utilizar bots automatizados para manipular al electorado; y denunciar las noticias falsas para evitar el daño que generan" (https://pactoeticodigital.com/).

El Instituto Nacional Electoral (INE) mexicano, para las elecciones generales de julio de 2018, se alió con plataformas como Facebook para el desarrollo de acciones tendientes a depurar la información que llega a los electores; se estableció un canal de comunicación entre la autoridad electoral y la red social para la certificación de noticias, se favoreció la divulgación de videos informativos y se afincó la cooperación con plataformas informativas como \#Verificado2018 (@VerificadoMX) para alertar sobre informaciones inexactas (ver comunicado de prensa Facebook e INE anuncian colaboración para elecciones; disponible en: https://centralelectoral.ine.mx/2018/02 /05/facebook-e-ine-anuncian-colaboracion-para-elecciones/).

Esos ejemplos de experiencias comparadas (elegidos bajo criterios de conveniencia sin ningún afán de generar datos representativos) permiten ilustrar las dos tendencias que, sobre el uso de redes sociales y sus derivados, existen hoy. Como lo señaló el magistrado presidente del Tribunal Supremo de Elecciones de Costa Rica (TSE), Dr. Luis Antonio Sobrado González, en la audiencia de reelección celebrada en la Corte Suprema de Justicia el 11 de febrero de 2019:

...hay dos respuestas que estamos viendo en el mundo; una respuesta punitivista que lo que propone es cárcel para aquellos que difundan noticias falsas [...]. Hay una vía alternativa a la vía punitiva, a la vía de la imposición y es alentar extraordinarios ejercicios periodísticos [...] de medios de comunicación que a través de su reconocimiento y prestigio nos han ayudado a la colectividad a cribar lo que es la verdad de lo que es la desinformación. (disponible en el sitio: https://livestream.com/poderjudicial-costarica/11Febrero2019 /videos/187187612, secuencia de la hora 1:57 a 2:02). 


\section{DERECHO EIECTORAL}

En resumen, por un lado se tiene la opción de criminalizar las conductas relacionadas con las noticias falsas y, por otra parte, está la de generar espacios en los que otros actores sociales (como medios de comunicación, formadores de opinión e instancias de la sociedad como las universidades) se den a la tarea de señalar aquellas informaciones que no se corresponden con la verdad.

Siguiendo la lógica de esos dos escenarios, conviene afirmar que la vía legislativa obliga a reflexionar sobre algunos tópicos metajurídicos. En Internet todo se mueve en tiempo real y se da, además, una potencial virulencia; también hay una indeterminación de receptores porque -cuando algo se coloca en la red- no se sabe cuántas personas lo van a ver. A lo anterior debe sumarse la imposibilidad material de conocer el impacto: se puede saber cuántos vieron el posteo, mas no cuál fue la incidencia en la intención de voto, por ejemplo.

Importa también tener presente que, pese a las convenciones sobre el derecho al olvido (como prerrogativa humana), Internet no olvida: en Costa Rica, una persona que trabaja en el servicio de salud estatal (odontólogo jefe de la Sección Maxilofacial de un hospital público) hizo una fuerte crítica -en sus redes sociales- contra una legisladora; para ello, se sirvió de términos desdeñosos ${ }^{17}$. El autor del comentario bajó el posteo 5 minutos después, pero ya toda la prensa había hecho capturas de pantalla (screenshots) y eso sirvió para que fuera noticia por 2 o 3 días; incluso, semanas después seguía discutiéndose el asunto y su relación con el acoso político contra las mujeres en el ejercicio de cargos públicos.

Esas especificidades propias del espacio virtual deben conjugarse con referentes jurídicos para un abordaje comprensivo del fenómeno (es claro que ello dificulta el tratamiento legislativo que habrá de darse). Así, si se desean disvalorar las conductas cometidas en el espacio cibernético deben tenerse en mente al menos dos perspectivas: a) la primera es entender las plataformas como medio para cometer faltas y delitos, pero no es ese el elemento medular. En el caso costarricense, está prohibida la divulgación de información de encuestas y sondeos de opinión los tres días antes y el

\footnotetext{
17 El odontólogo escribió en su muro de Facebook: "Que jaiba y pola es esta Ramasheka, además de tonta y necia. Es más, para mí es tan fea tan fea que si en vez de diputada hubiera sido prostituta seguro muere virgen. (...) Y lo peor es que está en la Asamblea haciendo estupideces. Todo un personaje". Ver noticia: "INAMU y diputados piden investigar y que se tomen medidas de peso contra médico por comentario machista" en Costa Rica medios (SINART): http://costaricanoticias.cr/detalle/2903/inamu-y--diputados-piden-investigar-y-que-setomen-medidas-de-peso-contra-medico-por-comentario-machista.
} 


\section{DERECHO ELECTORAL}

propio día de la elección (artículos 138, 286 y 289 del Código Electoral); entonces, así se difunda por radio, televisión, pero también por Internet, la prohibición rige. En el último escenario, el medio de comisión de la falta es el ciberespacio, empero la falta no solo tiene esa modalidad de ocurrencia; en otros términos, no es que privativamente deba darse la conducta por la red. b) La otra opción de abordaje alude a aquello en lo que la acción desvalorada si está íntimamente ligada a una red social; acá podemos hablar de fake news o de memes que pudiesen disuadir la voluntad del electorado en favor de una u otra tendencia. Véase que ahí no es el mecanismo, sino que realmente no podríamos entender un meme fuera del mundo del Internet o las redes sociales.

En el primero de los supuestos descritos, la legislación se torna innecesaria, ya que, como se apuntó en el apartado anterior, la jurisprudencia electoral ha determinado que las actuales prohibiciones rigen tratándose de conductas cuyo medio de comisión sea Internet.

En la hipótesis b) el tema se complejiza aún más: la construcción de los tipos penales, los medios probatorios y el juzgamiento mismo de la conducta traen consigo dificultades adicionales. Por ejemplo, para poner sobre la mesa escollos en la determinación del presunto imputado (como elemento básico: a quién se va a juzgar una vez cometida la infracción), es menester generar una tipología de cibernautas.

Para iniciar, tendríamos a un sujeto que se puede denominar "el honesto", quien diría "sí yo dije eso en mis redes sociales y lo sostengo". En Costa Rica, hace algunos pocos años, la expresidenta Laura Chinchilla Miranda fue criticada en su muro de Facebook por un comerciante; ella, por considerar que lo indicado era afrentoso, interpuso una querella y él, durante todo el proceso, sostuvo que sí había escrito esa información.

Tenemos, también, los perfiles anónimos. En nuestro medio podemos recordar a quien -en redes- se hacía Ilamar "El Chamuco Costa Rica"; en su descripción mencionaba que era un funcionario público que denunciaba corrupción. Evidentemente, no había forma de identificarlo de manera directa.

Otra clasificación sería el "olvidadizo". Esta es la persona que dice "sí, mire ese es mi perfil, pero fue que yo dejé la cuenta abierta en la computadora de la oficina. Alguien llegó, seguro posteó algo, pero yo no lo hice"; frente a ese escenario, corresponderá desvirtuar esa coartada, tarea para el ente 


\section{DERECHO ELECTORAL}

fiscal que será más o menos dificultosa según haya otros indicios que favorezcan la inculpación.

De otra parte, puede hablarse del suplantador: persona que se hace pasar por otra y que podría estar haciendo acciones incorrectas a través de estos mecanismos. Finalmente, un troll: personaje ficticio, pero que tiene una cierta intencionalidad.

En todos los tipos descritos, salvo el honesto, surge el problema práctico de la imputación. Se puede propalar un bulo a través de un perfil cuyo apelativo haga presumir que hay detrás una persona real; no obstante, puede tratarse de una mera fachada que, sin ser detectada por el resto de usuarios de la red, sirvió para la propagación de una información inexacta o ilegítimamente tendenciosa.

Como un nuevo concepto que coadyuve a aminorar esas amplias posibilidades de escabullirse mediante planteamientos tan creíbles como el del olvidadizo, podríamos hablar de una "posesión pública y notoria del perfil". Si el perfil es conocidamente suyo, si tiene sus amigos, si ya todo mundo sabe que esa es su línea de pensamiento y forma de hablar (escribir), entonces podría afirmarse una presunción de que usted fue el autor de la noticia falsa; en esa ilación habría que preguntarse si se está invirtiendo la carga de la prueba o no, tomándose en consideración que, en ciertas materias, no es extraño que se generen espacios de discusión sobre ese tema: en hostigamiento sexual hay una suerte de matización de la referida carga. En el derecho electoral sancionatorio podría darse también el respectivo y sesudo análisis sobre el particular como paso previo a legislar.

Otro problema práctico que debe estudiarse, si se opta por la opción de la criminalización de conductas, es cómo habrá de entenderse o si será necesario -más bien- alejarse del principio de territorialidad. ¿Qué pasa si la noticia falsa se generó en México y afectó el proceso electoral en Costa Rica, mas el servidor en el que se alojó la información se ubica en Estados Unidos?; alguien podría decir: bueno es que si el resultado se produce en el país, por principio de territorialidad, aplica allí el derecho de ese sitio, lo cual es cierto si el delito o la falta es el resultado, pero si es de mera actividad no. Por eso, en otro espacio, lo que se ha sugerido aplicar es el principio real o de defensa: el Estado puede aplicar su ley nacional cuando se contravienen o se ponen en riesgo los bienes jurídicos nacionales y estos son los que le dan estabilidad a la nación; qué más requisito para ello que 


\section{DERECHO ELECTORAL}

un sistema democrático sano (Cambronero, 2018). De esa forma, se podría aplicar la ley a acciones de mera actividad y evitaría, de alguna manera, el tener que medir el impacto que puede generar o no una noticia falsa.

Precisamente ligado con lo anterior, aparece la obligada pregunta de qué es lo que se desea punir: conductas de resultado o de mera actividad. Si la conducta se configura en la norma como una falta o un delito de resultado, habría que medir ese resultado. O sea, habría que demostrar que realmente se movió la aguja de la voluntad popular hacia un lado o el otro, pero si se decanta por ilícito de peligro, la mera actividad (el mero posteo) acarrearía responsabilidad para la persona.

Líneas atrás afirmábamos la imposibilidad de cuantificar el impacto de un meme o una noticia falsa en el resultado electoral. En este momento, no están claros cuáles serían los indicadores para diagnosticar esa incidencia $y$, con base en esta, determinar si se podría argumentar una afectación al resultado que lleve a la nulidad de la elección, circunstancia que debería ser suficiente para descartar las conductas de resultado en los términos expuestos. De otra parte, véase que incluso si eso fuera posible (precisar el impacto), los tiempos de juzgamiento para decretar o anular la elección deben ser tomados en consideración al momento de legislar.

En el juzgamiento de toda ilicitud debe asegurarse el debido proceso y eso toma tiempo. Entonces, si la incorrección va a incidir en el resultado o la nulidad de la elección, habría que readecuar todas las etapas procesales tomando en cuenta el calendario electoral, máxime que -en el caso costarricense- el TSE es un órgano jurisdiccional creado para arbitrar las disputas electorales (ordinales 9, 99 y 102 constitucionales), pero la instancia encargada de procesar los delitos electorales es el Ministerio Público y, consecuentemente, la jurisdicción penal ordinaria (numeral 285 del Código Electoral). De esa suerte, habría que generar mecanismos para compaginar los tiempos de ambas instancias, pues una vez declarada la elección, su validez no puede volverse a discutir.

En el proyecto de ley n. ${ }^{\circ}$ 21187, denominado "Ley contra la ciberdelincuencia", los legisladores pretenden incorporar un tipo penal que, por su construcción, parece no considerar las observaciones de los párrafos precedentes. En efecto, la pretendida modificación al artículo 236 del Código Penal sanciona con pena privativa de libertad de uno a cuatro años "a quien fabrique y difunda, a través de medios informáticos, una noticia falsa con 


\section{DERECHO ELECTORAL}

el fin de afectar la decisión del electorado en un proceso de plebiscito, referéndum o electoral nacional o extranjero".

Como puede observarse, se crea una figura de tendencia interna trascedente, esto es que debe acreditarse que la elaboración y divulgación de la noticia falsa se hizo con un fin específico: falsear la libre decisión del electorado; de esa forma, quedan sin sanción las acciones que, pese a poder ser subsumidas en el tipo, su autor no tuvo otra intención que no fuera la de hacer una broma o molestar a un sujeto (o grupo). Además, la forma en que se redacta la acción típica da espacio a la interpretación que, por tratarse de materia penal, debe ser restrictiva.

Podría pensarse que hay dos conductas sancionadas: la elaboración y la divulgación; empero, la introducción de la letra " $y$ " entre ambos verbos llevaría a interpretar que el sujeto merecedor de sanción es aquel que elaboró la noticia falsa y, necesariamente también, la divulgó. En otros términos, si un individuo fabricó la información no veraz, mas no la circuló, entonces sería tan impune como el que la hizo de conocimiento general sin ser su autor (si el legislador deseaba disvalorar las dos conductas debió utilizar la partícula "o").

Otro de los aspectos que queda evidenciado en la propuesta legislativa es el interés sancionatorio basado en la prevención general negativa (disuadir la comisión de conductas como las reprochadas, amedrentar) y el castigo directo al infractor, en tanto la existencia del tipo no tendría incidencia sobre el resultado electoral (aun comprobado que una noticia falsa se propagó no habría forma de sustentar la nulidad de los comicios desde esa norma). Tampoco se ve una intención de que el asunto se resuelva antes de la votación (lo cual podría ser tomado en cuenta por el electorado como un elemento para decidir su voto), pues no se considera la duración promedio de un proceso penal ni se adscribe ese tipo de delincuencias a procedimientos expeditos, como podría serlo el de flagrancia. Quizás el único elemento que se ajusta a lo expuesto hasta el momento es la configuración de un tipo de peligro.

Llegados a este punto pareciera que la opción menos problemática es la no legislativa: trabajar en plataformas de validación de la información en manos de actores sociales (como medios de comunicación y la academia), reservándose la intervención de la autoridad electoral a aquellas noticias inexactas que pongan en entredicho la transparencia o confiabilidad del proceso (en ese escenario se entiende que el árbitro de la contienda debe 


\section{DERECHO EIECTORAL}

aclarar los rumores) y en los casos en que se deban tutelar derechos fundamentales, sea cuando lo propalado tenga la entidad suficiente para acreditar una relevante lesión a la libre determinación del votante ${ }^{18}$ (supuesto en el que se entiende habilitada la vía del amparo electoral). Sobre esto último, convendrían estudios que se pregunten por el contenido de una sentencia estimatoria, qué se ordenaría: ¿bajar la información?, ¿una rectificación? y ¿cómo medir el impacto?

Esa participación limitada de la autoridad electoral se justifica en que la actuación del poder público incide en la intención de voto: si el árbitro de la contienda se dedica a aclarar las noticias falsas o afrentosas para alguno de los contendientes, entonces los otros partidos o agrupaciones podrían decir que hay parcialidad, sin contar que las personas podrían dudar de la legitimidad del proceso o, en su defecto, volcarse hacia la tendencia que resulta afectada por la defensa que de ella hace el regente del proceso.

En este tema la participación de los titulares públicos es altamente peligrosa, tanto si se criminalizan las conductas a través de leyes penales como si se autoriza legalmente al organismo electoral para aclarar o invalidar afirmaciones, el resultado es el reconocimiento de que la verdad vendrá dada desde la institucionalidad, pudiéndose caer en ejercicios autoritarios del poder o en limitaciones arbitrarias a la libertad de expresión.

Ante ese panorama lo mejor es poner el aparato institucional al servicio de otros intervinientes que, con voces diversas y cualificadas, plateen ejercicios serios de control cruzado de las informaciones, iniciativas que, además, fortalecen la ciudadanía activa como componente fundamental de la partitura democrática.

\section{Reflexión final}

La discusión acerca de las redes sociales recién inicia. El mundo se ha enfrentado a cambios vertiginosos en las formas de comunicarse $y$, de gran relevancia, de acceder a la información. Ciudadanos, candidatos y partidos

\footnotetext{
18 Un buen criterio de admisibilidad -que podría utilizarse en esos casos- es el de la relevancia, reiteración o intensidad que evidencie la presunta afectación alegada, tal y como lo evalúa el TSE en los casos de amparo electoral por propaganda en la que se invocan motivos religiosos (sobre el punto ver, entre otras, las sentencias n. ${ }^{\text {os }} 1762-\mathrm{E} 1-2018$ y $\left.1375-\mathrm{E} 1-2018\right)$.
} 


\section{DERECHO ELECTORAL}

políticos hoy pueden interactuar como nunca antes; sin embargo, esas dinámicas no resultan ser sencillas en su comprensión ni en su regulación.

Investigaciones acerca de posibles injerencias de naciones extranjeras en procesos electorales nacionales, la propagación deliberada de noticias falsas y máquinas y algoritmos que tratan de influir en las opiniones son solo algunos de los elementos que componen un fenómeno tan complejo como volátil: la evolución del mundo virtual siempre tendrá un ritmo acelerado y poco predecible en relación con las soluciones que, desde la institucionalidad, puedan darse. Por ello, cualquier iniciativa que desee plantearse en este campo debe tomar en consideración limitaciones de origen (el tiempo de reacción es una de ellas) y apostar por la flexibilidad.

La soberanía de los Estados, anclada en referentes teóricos que aluden a conceptos como el de territorio, no es suficiente cuando de la red se trata; la posibilidad de generar falsedades afuera de la jurisdicción de las autoridades nacionales o la gran dificultad para individualizar a los responsables de una acción que se traduce en bytes, lejos de amilanarnos deben ser el acicate para no optar por una solución apresurada que, más bien, genere un efecto contrario al deseado.

Desde esa perspectiva, recurrir a propuestas legislativas cuyo diseño corresponde al punitivo clásico no pareciera ser la vía adecuada; más allá del necesario debate acerca de si, en democracia, conviene que el poder público ande por ahí definiendo qué es la verdad, no deben eclipsarse los condicionamientos que presenta el entramado jurídico: ¿servirá el derecho, como tecnología social, para enfrentar los múltiples desatinos de los cibernautas?

Mientras se llega a una postura concluyente sobre ese tema, conviene mirar las experiencias de otros sitios, donde las alianzas público-privadas y el ejercicio de un periodismo responsable han permito contener los embates de las acciones maliciosas que pueden provenir de muros y de perfiles.

Si bien podemos tener discrepancias en las vías, lo cierto es que existe un punto de partida común: la mentira no conviene en las dinámicas políticoelectorales y no se vale torcer la voluntad de los electores a golpe de farsas. Precisamente, ese aspecto -reflejo de un objetivismo moral-debe hacernos críticos, al tiempo que nos debe reforzar el ánimo hacia salidas pragmáticas. 


\section{DERECHO EIECTORAL}

En pocos meses estaremos en un proceso que, si se cumplen las predicciones de la administración electoral, tendrá más de un centenar de partidos políticos y convocará a más de cincuenta mil candidaturas; esas características permiten aventurar hipótesis sobre un uso masivo de redes y perfiles. No obstante, la legislación, tratándose de los espacios virtuales, es prácticamente ausente; no sé si el camino sea el de las reglas, pero la realidad es que estas aún no están.

Por tales motivos, se impone una madurez y un pragmatismo, se requiere el compromiso de los actores sociales y de una ciudadanía responsable en doble vía: no creer todo lo que se escucha, hay que verificarlo; y, en otro sentido, no ser cajas de resonancia de mensajes insidiosos. En todo caso, se requiere que empecemos a examinar profundamente este nuevo fenómeno.

\section{Referencias bibliográficas}

Acuña, B. (2011) La socialización a través de las redes. Recuperado de: https://dialnet.unirioja.es/servlet/articulo?codigo $=4125886$

Adorno, T. (2007) Dialéctica de la ilustración (Obra completa 3). Madrid: Ediciones Akal.

Alvarado, J. (10 de febrero, 2018) Coalición Costa Rica hace su primera aparición en público. Diario Digital crhoy.com. Recuperado de: https://www.crhoy.com/nacionales/coalicion-costa-rica-hace-su-primeraaparicion-en-publico/

Ayala, T. (Ene.-Jun., 2014) Redes sociales, poder y participación ciudadana. Revista Austral de Ciencias Sociales, (26), 23-48. Recuperado de http://www.redalyc.org/pdf/459/45931862002.pdf

Blumer, H. y Mugny, G. (1992). Psicología social. Modelos de interacción. Buenos Aires: CEAL.

Cambronero, A. (2018). La justicia penal electoral en Costa Rica. Costa Rica: IFEDTSE.

Castells, M. (2012.) Redes de indignación y esperanza. Madrid: Alianza Editorial. 


\section{DERECHO EIECTORAL}

Comisión Europea (2018) Combatir la desinformación en línea: La Comisión propone un Código de Buenas Prácticas para toda la UE. Comunicado del 26 de abril. Recuperado de europa.eu/rapid/press-release_IP-18-3370_es.pdf

Costa Rica. Asamblea Legislativa (2018). Proyecto de ley para combatir la ciberdelincuencia. Expediente legislativo n. ${ }^{\circ} 21187$.

Costa Rica (2009). Código Electoral. Ley 8765, del 19 de agosto. Publicada en el Alcance n. ${ }^{\circ} 37$ de La Gaceta n. ${ }^{\circ} 171$ del 2 de setiembre.

Costa Rica (2005). Constitución Política de la República de Costa Rica. San José: Editorial Investigaciones Jurídicas

Costa Rica. Poder Judicial (2019). Sesión de Corte Plena del 11 de febrero. [Video podcast]. Recuperado de https://livestream.com/poderjudicialcostarica/11Febrero2019/videos/187187612

Francia. Asamblea Nacional (2018). Ley n ${ }^{\circ}$ 2018-1202 de 22 de diciembre relativa a la lucha contra la manipulación de la información.

Forni, P. (2003). Las metodologías de George Herbert Mead y Herbert Blumer. Similitudes y diferencias. Documento de Trabajo n. ${ }^{\circ} 14$. El Salvador: Instituto de Investigación en Ciencia Sociales de la Universidad del Salvador. Recuperado de http://csoc.usal.edu.ar/archivos/csoc/docs/idicso-sdti014.pdf

Joas, H. (1991). Interaccionismo simbólico. En: La teoría social hoy, pp. 112- 154. México: Alianza Editorial.

Láscares, C. (9 de junio, 2018). Ministro de Educación se disculpa por tuit sobre suicidio. La Nación, edición digital. Recuperado de https://www.nacion.com/elpais/educacion/ministro-de-educacion-se-disculpa-por-tuitsobre/OLDKHAFK7FDDBM6WPFAPIER7IY/story/

Le Bon, G. (1995). Psicología de las masas. Tercera edición. Madrid: Morata.

Mead, G. (2004). The Self: the I and the Me. En Hatch, M. y Schultz, M. (editors). Organizational Identity: A Reader. Londres: Oxford Management Readers.

Mead, G. (1934). Mind Self and Society from the Standpoint of a Social Behaviorist. Chicago: University of Chicago.

Mead, G. (1913). The Social Self. The Journal of Philosophy, Psychology and Scientific Methods. 10(14), 374-380. 


\section{DERECHO EIECTORAL}

Mejía, J. (2018). Estadísticas de redes sociales 2018: Usuarios de Facebook, Twitter, Instagram, YouTube, LinkedIn, Whatsapp y otros. Recuperado de https://www.juancmejia.com/marketing-digital/estadisticas-de-redes-socialesusuarios-de-facebook-instagram-linkedin-twitter-whatsapp-y-otros-infografia/

México. Instituto Nacional Electoral (2018). Facebook e INE anuncian colaboración para elecciones". Comunicado de Prensa. Recuperado de https://centralelectoral.ine.mx/2018/02/05/facebook-e-ine-anunciancolaboracion-para-elecciones/).

Murillo A. (7 de mayo, 2018). Carlos Alvarado, el presidente atrevido de Costa Rica. Diario Digital El País. Recuperado de https://elpais.com/internacional/2018/05/07/america/1525706014_193325.html

Neumann, E. (1995). La espiral del silencio. Opinión pública: nuestra piel social. España: Paidós.

Organización de Estados Americanos (2001). Carta Democrática Interamericana. Recuperada de http://www.oas.org/OASpage/esp/Documentos/ Carta_Democratica.htm

Perlo, C. (2006). Aportes del interaccionismo simbólico a las teorías de la organización. Revista Austral de Ciencias Sociales, (16), 89-107. Recuperado de http://www.redalyc.org/articulo.oa?id $=87701607$

Redacción del medio digital CRHOY.com (6 de abril, 2019). Diputado Pablo Abarca: El ropero de Paté es bien grande. Diario CRHoy. Recuperado de https://www.crhoy.com/nacionales/diputado-pablo-abarca-el-ropero-pate-esbien-grande/

Ritzer, G. (1993). Interaccionismo simbólico. En Ritzer, G. Teoría sociológica contemporánea, pp. 213-262. México: McGraw-Hill/Interamericana de España.

Sibila, P. (2008). La intimidad como espectáculo. Buenos Aires: Fondo de Cultura Económica.

Shane, S. (19 set., 2017). Rusia creó perfiles falsos de estadounidenses para influenciar en las elecciones. New York Times. Recuperado de https://www.nytimes.com/es/2017/09/19/rusia-facebook-perfiles-falsoselecciones-eeuu/

Simmel, G. (1939). Sociología: estudios sobre las formas de socialización. Buenos Aires: Espasa-Calpe. 


\section{DERECHO EIECTORAL}

Tocqueville, A. (1989). El antiguo régimen y la revolución. Segunda edición. Madrid: Alianza.

Valerio, M. (1 de agosto, 2018) INAMU y diputados piden investigar y que se tomen medidas de peso contra médico por comentario machista. Costa Rica medios (SINART). Recuperado de http://costaricanoticias.cr/detalle/2903/inamu-y-diputados-piden-investigar-y-que-se-tomen-medidas-de-peso-contra-medicopor-comentario-machista.

Weidenslaufer, C. (2019) La regulación de las "fake news" en el derecho comparado. Chile: Asesoría Técnica Parlamentaria Biblioteca del Congreso Nacional. Recuperado de https://www.bcn.cl/obtienearchivo?id=repositorio/10221/26901 /1/Regulacion_de_las_fake_news_2018.pdf

\section{RESOLUCIONES}

Tribunal Constitucional Federal alemán (1983). Sentencia bVerfGE 65 caso ley de censo del 15 de diciembre.

Tribunal Supremo de Elecciones (2018). Resolución n. ${ }^{\circ}$ 3252-E1-2018 de las 10:45 horas del 4 de junio.

Tribunal Supremo de Elecciones (2018). Resolución n. ${ }^{\circ}$ 2152-E4-2018 de las 13:00 horas del 10 de abril.

Tribunal Supremo de Elecciones (2018). Resolución n. ${ }^{\circ}$ 1762-E1-2018 de las 11:15 horas del 21 de marzo.

Tribunal Supremo de Elecciones (2018). Resolución n. ${ }^{\circ}$ 1375-E1-2018 de las 10:30 horas del 5 de marzo.

Tribunal Supremo de Elecciones (2018). Resolución n. ${ }^{\circ}$ 1265-E11-2018 de las 11:00 horas del $1 .^{\circ}$ de marzo.

Tribunal Supremo de Elecciones (2018). Resolución n. ${ }^{\circ}$ 970-E11-2018 de las 12:10 horas del 15 de febrero.

Tribunal Supremo de Elecciones (2017). Resolución n. ${ }^{\circ}$ 8080-E8-2017 de las 11:15 horas del 20 de diciembre.

Tribunal Supremo de Elecciones (2017). Resolución n. ${ }^{\circ}$ 1034-E7-2017 de las 9:15 horas del 2 de febrero. 


\section{DERECHO EIECTORAL}

Tribunal Supremo de Elecciones (2016). Resolución n. 7616-E8-2016 de las 13:00 horas del 15 de noviembre.

Tribunal Supremo de Elecciones (2014). Resolución sin número de las 15:30 horas del 5 de diciembre, dictada en las diligencias que se tramitaron en el expediente $n .^{\circ}$ 245-S-2014.

Tribunal Supremo de Elecciones (2014). Resolución n. ${ }^{\circ}$ 2575-E8-2014 de las 15:15 horas del 21 de julio.

Tribunal Supremo de Elecciones (2013). Resolución n. ${ }^{\circ}$ 4418-E8-2013 de las 15:20 horas del 2 de octubre.

Tribunal Supremo de Elecciones (2010). Resolución n. 6429-E7-2010 de las 8:30 horas del 19 de octubre.

Tribunal Supremo de Elecciones (2010). Resolución n. 5027-E8-2010 de las 13:00 horas del 26 de julio.

Tribunal Supremo de Elecciones (2010). Resolución n. ${ }^{\circ}$ 0063-E7-2010 de las 08:30 horas del 7 de enero.

Tribunal Supremo de Elecciones (2009). Resolución n. ${ }^{\circ}$ 5491-E7-2009 de las 11:20 horas del 8 de diciembre.

Tribunal Supremo de Elecciones (2009). Resolución n. ${ }^{\circ}$ 5490-E7-2009 de las 11:10 horas del 08 de diciembre.

Tribunal Supremo de Elecciones (2009). Resolución n. ${ }^{\circ}$ 0978-E8-2009 de las 11:45 horas del 19 de febrero.

Tribunal Supremo de Elecciones (2006). Resolución n. ${ }^{\circ}$ 2694-E-2006 de las 10:00 horas del 4 de setiembre. 